University of Nebraska - Lincoln

DigitalCommons@University of Nebraska - Lincoln

Faculty Publications: Political Science

Political Science, Department of

December 2007

\title{
A Systematic Analysis of the Deracialization Concept
}

\author{
Byron D. Orey \\ borey2@unl.edu \\ Boris E. Ricks \\ University of Missouri, Kansas City, \& Pomona College
}

Follow this and additional works at: https://digitalcommons.unl.edu/poliscifacpub

Part of the Political Science Commons

Orey, Byron D. and Ricks, Boris E., "A Systematic Analysis of the Deracialization Concept" (2007). Faculty Publications: Political Science. 24.

https://digitalcommons.unl.edu/poliscifacpub/24

This Article is brought to you for free and open access by the Political Science, Department of at DigitalCommons@University of Nebraska - Lincoln. It has been accepted for inclusion in Faculty Publications: Political Science by an authorized administrator of DigitalCommons@University of Nebraska - Lincoln. 


\title{
A Systematic Analysis of the Deracialization Concept*
}

\author{
Byron D'Andra Orey \\ Department of Political Science \\ University of Nebraska, Lincoln \\ Boris E. Ricks \\ Department of Political Science \\ University of Missouri, Kansas City \\ \& Mellon Postdoctoral Fellow (2004-2006), \\ Pomona College
}

\begin{abstract}
*Acknowledgements: An earlier version of this paper was presented at the Western Political Science Association's annual meeting in Denver, Colorado. We are especially thankful to Michael Preston, Richard Engstrom, William Nelson, Janelle Wong and Renford Reese for their prior comments. Of course, only the authors can be responsible for the analyses and interpretations presented here. We would like to especially thank Dan Orey, Jr. (1941-2006) who encouraged both of us to make the best of our education while matriculating as student/athletes at his/our alma mater, Mississippi Valley State University.
\end{abstract}

\section{Introduction}

The concept of deracialization gained notoriety following elections held in November of 1 1989. During these elections, a number of African-American candidates captured victories in majority-white electoral jurisdictions, leading McCormick (1989: 1) to coin this Election Day as "Black Tuesday." Among those elected on "Black Tuesday" include: L. Douglas Wilder as governor of Virginia, David Dinkins as mayor of New York City, Norman Rice as mayor of Seattle and Chester Jenkins, mayor of Durham, North Carolina. In this article we systematically examine the deracialization construct/strategy and the potentially damaging impact that such a strategy might pose on the black community.

The evolution of the deracialization concept

McCormick and Jones (1993) formally define deracialization as, "conducting a campaign in a stylistic fashion that defuses the polarizing effects of race by avoiding explicit reference to race-specific issues, while at the same time emphasizing those issues that are perceived as 
racially transcendent, thus mobilizing a broad segment of the electorate for purposes of capturing or maintaining public office" (76). The concept was first introduced in 1973 by political scientist, Charles Hamilton, at a National Urban League meeting. The purpose of the meeting was to assemble a group of scholars, activists, and public officials to discuss strategies for organizing in the "post-protest" phase of the civil rights movement. During this meeting, Hamilton presented a brief essay that offered some possible strategies for achieving his goal. He encouraged blacks to develop coalitions with other races, especially whites (Hamilton 1973). As a means of gaining white support, Hamilton suggested that blacks should address social issues that made broad appeals to society as a whole. For Hamilton, one such issue was "full employment," which he considered the most important issue facing the black community and also an issue equally appealing to whites.

In 1976, Hamilton revisited the concept of deracialization in a position paper commissioned by the Democratic Party. During this presentation, he advised presidential candidates to emphasize issues that would attract voters across racial lines (Hamilton 1977). Hamilton argued that programs targeted directly at minorities failed to capture white votes. Thus, he urged civil rights groups and the Democratic Party to work for "deracialized solutions" such as national health insurance and an income maintenance program (McCormick and Jones 1993: 70). William Julius Wilson (1990) expanded upon Hamilton's message by suggesting that the Democratic Party embrace a progressive "race neutral program." Wilson stated that blacks and liberals who have pushed "a race specific agenda" (e.g., affirmative action, minority set-asides, busing) create a major barrier to those advocating broader programs that would be more attractive to white voters.

Hamilton's advocacy for the deracialized strategy sparked an interest among students of black politics (see e.g., Persons 1993; Perry 1991 and 1996). The preponderance of studies employing the concept of deracialization, however, has not been based on the systematic analysis of evidence. A typical study in this area simply presents conclusions drawn by the researcher with no indication of the methods or standards employed to arrive at such conclusions. In this article our goal is to improve upon the extant literature by creating a quantifiable measure of the deracialization construct. In doing so, we conduct an empirical analysis for the purpose of systematically testing the construct's validity.

\section{Deracialization and its Application}

According to McCormick and Jones (1993: 76), a deracialized political strategy affects the issues candidates stress, their mobilization tactics and the style of their campaigns. Their model cautions black candidates who run in racially competitive districts/jurisdictions to avoid race-specific campaigns. According to this model, black candidates in such positions should avoid using explicit references to issues such as welfare, affirmative action and set-asides. Rather, they should place emphasis on issues that appear to be race-neutral. In addition to the avoidance of race-specific issues, the deracialized strategy also involves the campaign tactics employed by black candidates to mobilize voters. The authors contend that black office seekers who run deracialized campaigns should avoid public appeals to the black community. Black candidates risk the potential of alienating the white electorate with the use of race-specific campaign tactics. In short, black candidates should be careful of not giving white voters the impression that they are only interested in representing blacks. The final component of McCormick and Jones's model is political style. The success of black candidates in attracting white support depends, in part, on their ability to project a nonthreatening image. It therefore is necessary for black candidates to project a reassuring image to the white electorate. Black candidates, for example, should avoid associating themselves with people that white voters will view as racial partisans. 
The scholarly debate on the issue of deracialization has evolved both normatively and empirically. Borrowing from the normative front, political scientist Ron Walters notes that "the available political jurisdictions that are majority black are drying up. So to increase the number of Black elected officials, they will have to come from majority white districts. You cannot run there in the same way as in a majority Black district and be successful." (quoted by Gurwitt 1990: 30). Confronted with this reality, both scholars and political pundits have argued that new strategies such as deracialization are necessary in order for more black candidates to be successful in the future. Others, on the other hand, view the use of this strategy with a jaundiced eye. Starks (1991), for example, has argued that the concept:

... cannot be permitted to divert attention from the essence of American politics-that is, the acquisition and maintenance of group power. Nor can it be permitted to divert from the substance of what constitutes African-American politics-using electoral politics as a lever to maximize group power in the fight against racism, exclusion, and marginalization while promoting African-American-specific policy preferences within the political system (Starks 1991: 216).

In a case study of L. Douglas Wilder's election as governor of Virginia in 1989, Jones and Clemmons (1993), note that Wilder presented himself as a "social moderate and fiscal conservative who represented the 'New Virginia Mainstream'-a major theme of the campaign" (140). In determining whether Wilder conducted a deracialized campaign, these authors systematically examine Wilder's appointment book. The results reveal that between June 19 and September 4, 1989, Wilder appeared before the public eighty-four times. Jones and Clemons (1993) dichotomize the groups Wilder addressed, as being predominantly-white or predominantly-black, finding that only ten of these appearances were before black audiences. This research serves as one of the few systematic analyses conducted on the deracialization concept to date.

Schexnider (1990) extends his analysis to move beyond Wilder's gubernatorial race. He argues that Wilder's deracialization strategy can be traced back as far as his 1985 campaign to become lieutenant governor of Virginia. According to the author, Wilder did not present himself to the Virginia electorate as a black candidate in 1985, rather Wilder focused on his legislative record and issues that appealed to all voters (e.g., economic, educational, and environmental). Schexnider cites the work of Yancey (1988) as support for his claims. Yancey states:

Wilder never mentioned race. He hammered away at why he was more qualified until the media and white voters finally had to pay attention. But his campaign never took on the aura of a black crusade. But Wilder knew he had to have the redneck and suburban vote to win and he went after it (Yancey quoted in Schexnider 1990: 155).

However, Yancey himself does not provide a systematic analysis for his conclusions (see, Yancey 1988: 17).

Wilson Goode was elected as the first black mayor of Philadelphia, Pennsylvania in 1983. In examining Goode's campaign strategy, Ransom (1987) writes, "Goode did not portray himself as a 'black' candidate for mayor; instead, he campaigned as the former city managing director-he was familiar with city services; he knew the budget; he had demonstrated his managerial skills; and he had a vision of Philadelphia on the move" (276). Ransom continues by stating that Goode placed emphasis on his experience and background, and voiced the necessity of a partnership between the public and private sectors. Despite such claims, the author fails to reference any support for his claims.

The above examples are typical of studies in this area. They simply present conclusions drawn by the researchers with very little mention of the methods or inferential standards employed to arrive at such conclusions. Such presentations are difficult, if not impossible, to replicate and 
evaluate. ${ }^{1}$ For example, no systematic content analysis of the media coverage of a campaign is provided. In only a few cases, as well, are there references to elite interviews with people in a position to know about the election campaigns (e.g., Summers and Klinkner 1996).

Even in the few cases in which a systematic analysis was attempted, it is often flawed. Katherine Underwood (1997) utilizes the deracialization concept in her investigation of the campaigns of Latino candidates for the city council elections in Los Angeles, California. She reports that Latino candidates were able to build cross-racial support by running deracialized campaigns. Underwood employs multiple regression to examine the causation of the vote for Latino candidates as a function of the voting age population by ethnic group. However, Underwood's findings are marred by mistakes. Criticism of the analysis is best stated in her own words: "The independent variables constructed result in near perfect multicollinearity. To the extent that the four ethnic categories (white, African American, Latino, and Asian) exhaustively include the precinct population, the value of the fourth category is almost perfectly determined by the other three" (Underwood 1997: 13). In the worst case, multicollinearity inflates the standard errors of the correlated variables and attenuates the statistical significance of the unstandardized coefficients.

Sharon Wright's (1996: 157) racially polarized voting analysis of the 1991 mayoral election in Memphis, Tennessee serves as one of the few analyses to systematically examine the impact of a candidate's campaign strategy. According to her analysis, Willie W. Herenton, the black candidate, is reported to have received roughly 98.5 percent of the black vote and only 1.5 percent of the white vote. On the other hand, Richard Hacket, a white candidate, received 98.5 percent of the white vote and only 1.5 percent of the black vote.

Elsewhere, Orey has attempted to strengthen the literature examining the deracialization construct, by conducting systematic analyses. In one analysis, Orey (n.d.) argues that the media should be employed as a contextual variable/effect, when examining the deracialization construct. Using content analysis, he finds that the print media helped to create a racialized environment, even when the black candidate attempted to run a deracialized campaign. Specifically, in using Jackson, Mississippi as a case study, Orey finds that the leading mainstream newspaper (i.e., paper with the highest circulation in the state), The Clarion Ledger, made more references to race in 1993 when the leading black candidate loss, than in 1997 when he won. Further, in a separate analysis, Orey (1999), in following the lead of Wright (1996), employs ecological inference to examine racial bloc voting in the 1993 and 1997 Jackson, mayoral election. He finds that the black candidate received more votes from both blacks and whites when he ran a race-specific campaign, than when he ran a deracialized campaign. In running a deracialized campaign, the candidate failed to win the primary, however, when he ran a race-specific campaign he was elected as the city's first black mayor.

\section{Where do we go from here?}

Albritton, et al. (1996) provide us with a template as to how to proceed in our efforts to measure deracialization. These authors create a typology for racial campaigns. They identify four categories of racial campaigns: (1) race-specific, (2) modified race-specific, (3) race-neutral and (4) extremely race-neutral. Conceptually, the authors make a much-needed contribution to the deracialization literature. However, these authors fail to provide a systematic method for distinguishing among their categories. In failing to create replicable measurements for their categories, the authors are unable to systematically analyze their data, which makes it very difficult to evaluate their work. 


\section{Data and Methods}

The data employed in this analysis are derived from the 2001 California Black Elected Officials Survey (Ricks, 2003). We first retrieved addresses for the 238 black elected officials in the state of California from the Joint Center for Political and Economic Studies. A survey was then mailed to all of the black elected officials in the state of California on August 15, 2001. The responses included seventy-four completed surveys. An additional twelve surveys were returned as undeliverable (because of incorrect addresses). As a result, our response rate, excluding the twelve undeliverable questionnaires, dips to 33 percent. Admittedly, this rate is somewhat lower than the 40 percent reported within the extant literature.

\section{Dependent Variables}

Using the above typology offered by Albritton et al., we operationalize deracialization based on the following item: "which of the following strategies best describe your campaign?" The responses included "race neutral (e.g., absence of racial cues; colorblind)", "race moderate (e.g., low use of racial cues, coalition building)" and "race specific (e.g., high use of racial cues; Afro-centric)." Given the fact that our analysis focuses on deracialization, we code the variable as a dichotomy, taking on a value of one, if the response is race neutral and zero otherwise. Given the dichotomous nature of the variable, logistic regression is employed.

In addition, we have created a measure for Black Interests to determine whether a black candidate who runs a deracialized campaign is more or less likely to support a black interest bill. To operationalize the Black Interest variable, we have created an additive-index scale based on three Likert response-format items: The leadership style of black elected officials differs from that of white elected officials; black voting districts should be exclusively represented by black elected officials; for black office seekers, identification with black issues is more important than coalition building. The scale's reliability is moderate, achieving an alpha score of .61. The additive-scale ranges from strongly agree to strongly disagree. Given the continuous nature of this variable, ordinary least squares regression is used.

\section{Independent Variables}

Deracialization also is measured on the right hand side of the equation. In addition, other independent variables include racial identification, which takes on a value of one if the respondent indicated that African-American best described his/her race and zero otherwise (i.e., Negro, Black, Colored, African, or some other label). Additionally, a number of control variables are included for the purpose of correctly specifying the model. Gender is a dichotomous variable that takes on a value of one if the respondent is male and zero for females. Education is a continuous variable ranging from lowest level of education (high school diploma or less) to highest level (postgraduate). Similarly, income ranges from lowest level of income (under $40 \mathrm{~K}$ ) to highest level of income (over $100 \mathrm{~K}$ ). Age is the actual age of the respondent. Ideology is based on a four point scale ranging from conservative to radical, with both moderate and liberal occupying the middle categories, in the order presented here. Democratic identification is represented as a dummy variable taking on a value of one if the respondent is Democrat and a zero otherwise. ${ }^{2}$

For ease of interpretation, all variables have been mapped onto a $[0,1]$ interval, with the exception of age.

Thus, our proposed models suggest the following relationships: 
(1) Deracialization = f(Age, Income, Education, Income, Racial Identification, Ideology, Democrat, Gender).

(2) Black Interests $=\mathrm{f}$ (Deracialization, Age, Income, Education, Income, Racial Identification, Ideology, Democrat, Gender).

\section{Findings}

Based on the descriptive statistics, black elected officials are more likely to identify their political campaign as being a race-neutral or a race-moderate campaign, as opposed to a racespecific campaign. According to Table 1, approximately 41 percent of the respondents indicated that their campaign style can best be described as race-neutral. A majority of the respondents (51 percent), however, identified their campaign as race-moderate. Only about eight percent of the respondents identified as running race-specific campaigns.

In addition to the campaign strategy, Table 2 provides a frequency distribution of the agree/ disagree responses of the Likert-items used to measure Black Interests. Based on these findings, roughly 52.2 percent of the respondents disagreed that "the leadership style of black elected officials differs from that of white elected officials, compared to 34.3 percent that agreed. Approximately 60 percent disagreed that "black voting districts should be exclusively represented by black elected officials, compared to 31.4 percent who agreed. Lastly, approximately 70 percent disagreed that "for black office seekers, identification with black issues is more important than coalition building," compared to 17.2 percent who agreed.

Using logistic regression, Table 3 provides the results for the explanations of deracialization. Based on the Odds-Ratios reported in Table 3, the findings reveal that older African-American leaders are roughly 5 percent more likely to adopt a deracialized strategy when compared to younger blacks. Additionally, those blacks who self-identify with the label African-American are found to be approximately 73 percent less likely to adopt a deracialized strategy when compared to those blacks identifying with some other label describing blacks. Lastly, blacks who self-identify as Democrats are 88 percent less likely to describe their leadership as race neutral. The models pseudo $r$-square is respectable at .28 .

Table 4 affords us the opportunity to determine if deracialization serves as an explanation for opposition to Black Interests. Based on the results, the deracialization variable achieves statistical discernability at the .05 level. No other variable in the analysis achieves statistical significance. The results presented here support the normative literature suggesting that those black leaders who identify with the deracialized leadership style are more likely to oppose/disagree with interests that are deemed to be progressive for the black community.

\section{Conclusion}

The preponderance of scholars conducting research on deracialization has failed to provide systematic analyses in drawing their conclusion. The typical study in this area has drawn conclusions without providing any indication of the methods or standards employed to make such inferences. The research here has created a quantifiable variable measuring deracialization. The construct is based upon previous definitions of the deracialization strategy. Here, we have focused on the issues and the campaign style. The validity of the measure was tested, by examining the impact of the deracialization variable on opposition to black interests. Based on the findings, those black elected officials who have identified their campaign strategies as race-neutral/deracialized, were less likely to support interests that have traditionally been found to be pertinent to the black community. Admittedly, we rely on extreme categories, due to data 
limitations. However, these issues are consistent with traditional issues addressed by black elected officials. Despite this shortcoming, this research note has provided us with a useful means for operationalizing the deracialization construct.

The implications of this study suggest that African Americans who run race-neutral campaigns have moved away from the protest approach used in the 1960 s and 1970 s to more accommodating campaign strategies. The overwhelming percentage of race-neutral and race-moderate campaigns endorsed by the respondents in this analysis suggest that African Americans have become more responsive to other groups, and place less emphasis entirely on Black Interests. Indeed, our multiple regression analysis finds that respondents who ran deracialized campaigns were less likely to endorse black interest policies. Interestingly, our findings also reveal that older legislators are more likely to identify their campaigns as race-neutral, when compared to their younger counterparts.

The findings discussed here have broader implications for students of black politics. black elected officials who run deracialized campaigns will also support race-neutral bills. Or, more important, these officials may fail to support black-interest bills. Future research examining the sponsorship of bills is needed if we are to gain a full understanding of the impact of the deracialization strategy on candidate's performance in office. Clearly, the current research is limited by our data and as a result, one should be careful in making generalizations based on our findings. Similarly, as always, when conducting case studies, caution should be used in making generalizations. Despite these shortcomings, we have attempted to generate research questions that may be answered in future research.

Table 1

Which of the following best describes your campaign strategy?

$\begin{array}{llc} & \text { Percent } & \text { Respondents } \\ \text { race-neutral (colorblind) } & 41 \% & 30 \\ \text { race-moderate (coalition-building) } & 51 \% & 38 \\ \text { race-specific (pro-Black) } & 4 \% & 3\end{array}$

Source: California Black Elected Officials (Ricks, 2003).

Table $2^{3}$

Questions used to construct the Black Interests Index

$\mathrm{N}=\mathbf{7 0}$

Percentage who indicated:

agree disagree

1. The leadership style of black elected officials differ

$52.2 \% \quad 34.3 \%$

from that of white elected officials.

$60 \% \quad 31.4 \%$

by black elected officials.

3. For black office seekers, identification with black issues $\quad 70 \% \quad 17.2 \%$

is more important than coalition building. 
Table 3

Logistic regression predicting Deracialization.

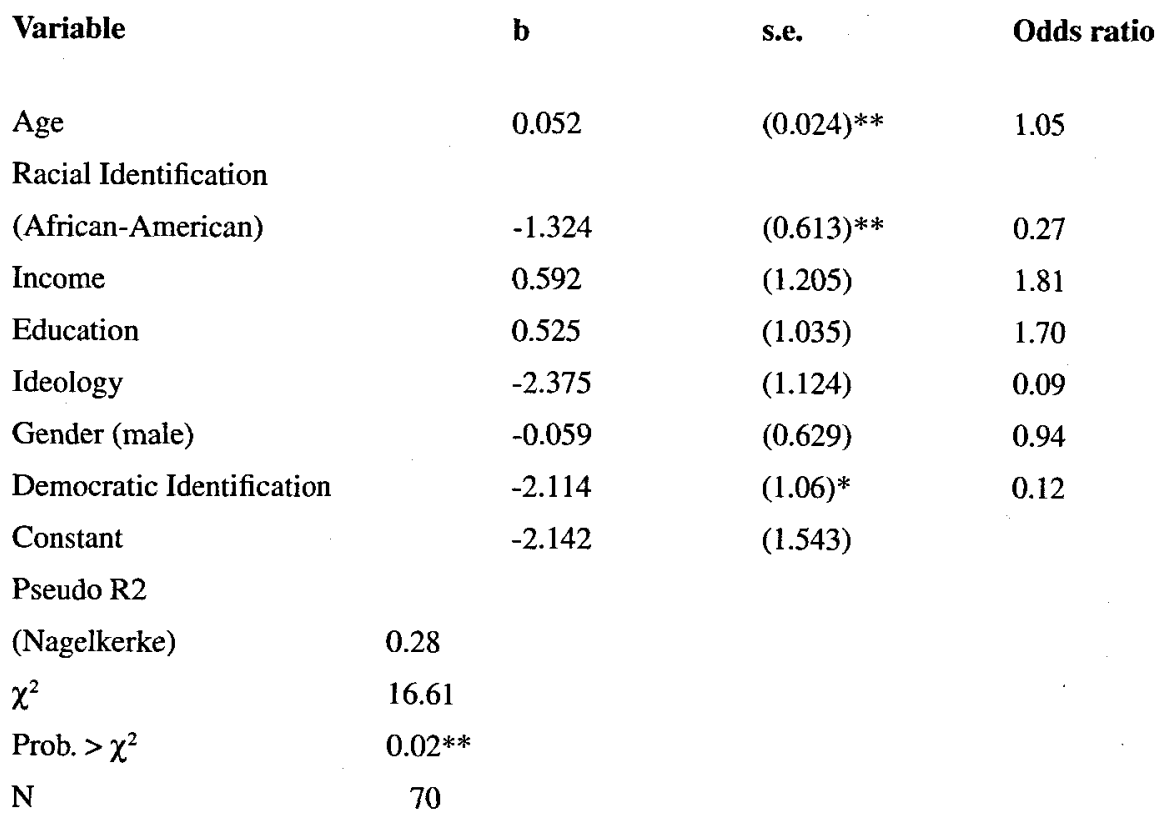

Note: ${ }^{*} \mathrm{p}<.05 ;{ }^{*} \mathrm{p}<.10$

Table 4

Opposition to Black Interests

$\begin{array}{lll}\text { Variable } & \text { b } & \text { s.e. } \\ \text { Deracialization } & 0.15 & (0.07)^{*} \\ \text { Ideology } & -0.10 & (0.13) \\ \text { Education } & 0.02 & (0.12) \\ \text { Income } & 0.07 & (0.13) \\ \text { Racial Identification } & & \\ \text { (African-American) } & 0.003 & (0.07) \\ \text { Age } & -0.002 & (0.002) \\ \text { Gender (Male) } & 0.02 & (0.07) \\ \text { Constant } & 0.60 & (0.16)^{* *}\end{array}$

R2 0.12

Adj. R2 0.02

$\mathrm{N} \quad 70$

Note ${ }^{*} \mathrm{p}<.05 * * \mathrm{p}<.01$ 


\section{Notes}

1. Krippendorf (1980: 145) suggests that the researcher "must describe the conditions under which data are obtained, justify the analytic steps taken, and see to it that the process is not biased in the sense that if favors one kind of finding rather than another. Explicitness about the process is required so that others may evaluate his work, replicate the process, or qualify the findings."

2. This decision was made because there is limited variation beyond identification with the Republican Party (e.g., Democrats represent roughly 84 percent and Republicans represent 13 percent of the sample).

3. All strongly agree/agree categories are collapsed into one category of agree, and all strongly disagree/ disagree categories were collapsed. Also, the percentages do not add up to 100 because a separate middle category capturing undecided respondents is not presented here.

\section{References}

Albritton, Robert B., George Amedee, Keenan Grenell and Don-Terry Veal. 1996. "Deracialization and the New Black Politics" in Race, Politics and Governance in the United States, (ed.) Huey L. Perry. Gainesville, FL. University Press of Florida: 96-106.

Gurwitt, Robert. 1990. "A Younger Generation of Black Politicians Challenges Its Elders." Governing the States and Localities (February).

Hamilton, Charles. 1973. "Full Employment as a Viable Issue." In When the Marching Stopped: An Analysis of Black Issues in the '70s. New York: The National Urban League: 87-91.

- 1977. "Deracialization: Examination of a Political Strategy." First World. March/April: 3-5.

Jones, Charles E. and Michael L. Clemons. 1993. "A Model of Racial Crossover" in Dilemmas of Black Politics, (ed.) Georgia Persons. New York. Harper Collins College Publishers, 66-84.

Krippendorff, Klaus. 1980. Content Analysis: An Introduction to its Methodology. Beverly Hills, CA: Sage Publications.

McCormick, J.P., II and Charles E. Jones. 1993. "The Conceptualization of Deracialization" in Dilemmas of Black Politics, (ed.) Georgia Persons. New York. Harper Collins College Publishers, 66-84.

McCormick, J.P., II. 1989. "Black Tuesday and the Politics of Deracialization." Paper delivered at a symposium, Blacks in the November '89 Elections: What is Changing." Sponsored by the Joint Center for Political Studies, Washington, DC. December 5, 1989.

Orey, Byron D'Andra. Forthcoming. "Framing the Issue, When the Issue is Race." International Journal of Africana Studies.

—_ 1999. Deracialization, Racialization or Something in Between: The Making of a Black Mayor in Jackson, Mississippi. Ph.D. Dissertation, University of New Orleans.

Perry, Huey. 1991. "Deracialization as an Analytical Construct in American Urban Politics." Urban Affairs Quarterly 27, 2 (December): 181-91.

-, (ed.) 1996. Race, Politics and Governance in the United States. Gainesville, FL: University Press of Florida.

Persons, Georgia A. 1993. Dilemmas of Black Politics: Issues of Leadership and Strategy. New York: Harper-Collins College Publishers.

Ransom, Bruce. 1987. "Black Independent Electoral Politics in Philadelphia and the Election of Mayor W. Wilson Goode." In The New Black Politics. (ed.) Michael Preston, Lenneal J. Henderson, Jr. and Paul L. Pureyar. White Plains: Longman: 256-293.

Ricks, Boris E. 2003. Califormia Black Elected Officials Survey Data/Codebook. In Black Elected Officials, Leadership Style and The Politics of Race: Los Angeles, 1963-2000. Ph.D. Dissertation, University of Southern California.

Schexnider, Alvin J. 1990. "The Politics of Pragmatism: An Analysis of the 1989 Gubernatorial Election in Virginia." Urban Affairs Quarterly, 27 December (2): 216-222.

Starks, Robert. 1991. "Commentary and Response to Exploring the Meaning and Implications on Deracialization in African-American Urban Politics." Urban Affairs Quarterly, 27 December (2): 216-222.

Summers, Mary E. and Phillip Klinkners. 1996. "The Election and Governance of John Daniels as Mayor of New Haven." In Race, Politics, and Governance in the United States, (ed.) Huey L. Perry. Gainesville, FL. University Press of Florida: 127-150.

Underwood, Katherine. 1997. "Ethnicity is Not Enough." Urban Affairs Review September 33 (1): 327. 
Wilson, William Julius. 1990. "Race neutral policies and the Democratic coalition." The American Prospect 1: 74-81.

Wright, Sharon. 1996. "The Deracialization Strategy and African American Candidates in Memphis Mayoral Elections." In Race, Politics and Governance in the United States, (ed.) Huey L. Perry. Gainesville, FL. University Press of Florida: 151-164.

Yancey, Dwayne. 1988. When Hell Froze Over. Roanoke, VA: Taylor Publishing Co. 